\title{
GCU
}

Glasgow Caledonian

University

University for the Common Good

\section{The shared learning journey: effective partnerships to deliver health promotion}

\section{Kempenaar, Larissa E.; Shanmugam, Sivaramkumar}

Published in:

Journal of Educational Innovation, Partnership and Change

DOI:

10.21100/jeipc.v4i1.731

Publication date:

2018

Document Version

Publisher's PDF, also known as Version of record

Link to publication in ResearchOnline

Citation for published version (Harvard):

Kempenaar, LE \& Shanmugam, S 2018, 'The shared learning journey: effective partnerships to deliver health promotion', Journal of Educational Innovation, Partnership and Change, vol. 4, no. 1.

https://doi.org/10.21100/jeipc.v4i1.731

\section{General rights}

Copyright and moral rights for the publications made accessible in the public portal are retained by the authors and/or other copyright owners and it is a condition of accessing publications that users recognise and abide by the legal requirements associated with these rights.

Take down policy

If you believe that this document breaches copyright please view our takedown policy at https://edshare.gcu.ac.uk/id/eprint/5179 for details of how to contact us. 


\title{
Case Studies
}

\section{The shared learning journey: effective partnerships to deliver health promotion}

\author{
Larissa E. Kempenaar, Sivaramkumar Shanmugam \\ Glasgow Caledonian University
}

\section{What is the challenge for healthcare professional education?}

Health promotion can be defined as "the process of enabling people to increase control over, and to improve, their health. It moves beyond a focus on individual behaviour towards a wide range of social and environmental interventions." (World Health Organisation, 2017). The need for all health professionals to act as 'agents of health promotion' was identified in 1986, in the Ottawa Charter. More recent strategy documents have identified the importance of providing health promotion within and with our local communities, rather than focusing on health promotion for patients after they have entered the healthcare system, as has been the case traditionally. The Shanghai Declaration (2016) states that all participants of the $9^{\text {th }}$ Global Conference on Health Promotion and the World Health Organisation (WHO) will commit to "re-orient health and social services to optimize fair access and put people and communities at the centre." Whilst most Allied Health Professionals (AHPs) in practice can identify their role as health promotion agents, health promotion tends to remain in one-toone, hospital-based settings (Needle et al., 2011). To develop healthcare professionals for the future, we therefore need to develop healthcare curricula which address the challenges of delivering collaborative health promotion in innovative ways to our local communities (Council of Deans, 2017).

For many public health issues, single approaches to health improvement are ineffective, because they do not recognise the complexity of people's social, economic and environmental circumstances. An assets-based approach is "one which seeks positively to mobilise the assets, capacities or resources available to individuals and communities which could enable them to gain more control over their lives and circumstances" (NHS Health Scotland 2011, p. 2). Assets-based relationships between health professionals and the public are founded on authenticity, honesty and mutual respect (Glasgow Centre for Public Health, 2011). The assets-based approach is, therefore, useful when collaborating with communities and fits well with the underlying principles of community-based health promotion to acknowledge the value of working with the public to enable them to capitalise on their determinants of health (Naidoo and Wills 2016). Working in partnership with our local communities provides a great opportunity for healthcare students to learn about community-based health promotion.

This paper provides an example of practice in which we transformed an existing paired partnership - between the module team and students on a pre-registration healthcare programme - into a three-way partnership between students, community partners and the module team. We outline the historical development of this partnership and discuss the impact this way of working has had on all involved.

\section{The Health Promotion Module}

The health promotion module was traditionally delivered through lectures supported by tutorials. The summative assessment consisted of a group presentation of a health promotion programme devised by the students for a selected (imagined) target audience. 


\section{Case Studies}

Students also had to design and produce a leaflet for patients on the health promotion programme. The module was delivered and assessed by academic staff, neither with contact with patient groups nor in collaboration with students. Student engagement had been reported as poor, as students did not view health promotion as a core skill to their development as allied health professionals. The lack of student engagement was demoralising, both for students and for the module team. Students therefore focused their efforts on the more traditional biomedically-oriented modules, where they learned about anatomy and physiology. Their lack of engagement also meant that students tended to adopt a biomedical approach to healthcare - with its focus on the biological aspects of health - in which knowledge about health is held by the 'expert' health professional and the patient is considered a recipient of care. Little consideration is given to the patient's psychosocial wellbeing (Naidoo and Wills, 2014).

\section{An attempt at a shared learning journey of lecturers and students}

When the first author became module leader in 2014, our module team decided to change the approach, in order to address this lack of engagement with the health promotion module.

Firstly, on the basis of the engagement-through-partnership framework (Higher Education Academy, 2014) and a social constructivist approach, we changed the teaching, learning and assessment strategy. Social constructivism is based on the work of Vygotsky (Papworth, 2016), who posited that knowledge is 'socially situated' and learning, therefore, takes place through social interactions. We thus included peer teaching and peer assessment, as we believed that learning takes place through social interaction and a consideration of the students' knowledge from their previous degree (students are on an accelerated MSc programme which allows them to register as Physiotherapists on successful completion). Furthermore, a social constructivist approach takes into consideration students' social and cultural background, which should enhance student engagement.

Because we used a social constructivist approach, we adopted a Progressivist ideology (Radu, 2011). A Progressivist ideology, based on Dewey's work, assumes that learning takes place by doing. Learning is therefore based on problem-solving (Radu, 2011). This presupposes the active participation of the student and a willingness to undertake a 'shared learning journey' with the module team. We embedded this within the module, by introducing students to the concept of engagement-through-partnership and then reviewing the module's learning outcomes. We invited students to develop learning plans and peer teaching, guided by the module team, on the basis of their learning needs as identified through the review of learning outcomes.

Peer teaching certainly increased engagement with the module, as students, during class time, enthusiastically took part in all the teaching and learning activities and demonstrated engagement. However, outside class time, they passionately expressed their discontent at this style of teaching and learning, in particular the peer-teaching aspect. The module team concluded that there appeared to be a discrepancy between staff and student expectations and experiences of teaching and learning (Trowler 2015b). What we had not anticipated was that students adopted a more Traditionalist ideology, owing to the learning environments they had been exposed to in previous degrees. A Traditionalist ideology is based on the expectation that knowledge and skills are transmitted from lecturer to student and module delivery is therefore 'lecturer-centred' (Sawers et al., 2016). In essence, whilst we had 


\section{Case Studies}

considered their existing knowledge and experiences of the content, we had not considered the educational ideology in which this had been developed.

This discrepancy in educational ideology between the module team and the students led to 'incongruent engagement' and discontent in students (Trowler 2015a). The educational 'leap' we had asked them to make had been too great in terms of facilitating their learning.

Students, therefore, were not ready to join this 'shared learning journey'. They had joined us, but very reluctantly. Furthermore, students continuously asked for more time to spend on the parallel-running module, in which they learned more biomedical principles - in terms of anatomy, physiotherapy assessment and interventions - rather than on the Health Promotion module. Partnership between lecturers and students had taken place, but 'happy' it was not.

\section{The second attempt at shared learning}

In 2015, the first author was invited to a network meeting between the University and staff from the Glasgow Science Centre, with the aim of setting up a University-Community partnership to provide health promotion activities for the Science Centre's BodyWorks exhibition. The BodyWorks exhibition is a hands-on display in the Science Centre, for the public to learn about the way the body works. The Science Centre uses a health literacy approach to health promotion, which assumes that providing people with relevant health knowledge will enable them to make informed choices (Christensen et al., 2016). This collaboration provided a welcome opportunity to facilitate students' engagement with a community-based organisation and allowed us to address the recent AHP strategy documents regarding the location of health promotion. In addition, 'service learning' (learning in community settings) can provide transformative learning (Felten and Clayton, 2011). The module aimed not only to increase student engagement, but also to encourage students to change their views of themselves - to see themselves more as health promotion agents and less as adopters of a biomedical approach (Butin, 2010).

The design of the health promotion activity for the service users of the partner organisations also meant that we could, potentially, provide the partners with health-promotion resources. Furthermore, the University aims to be a 'University for the Common Good'; certainly, its mission statement - "to make a positive difference to the communities we serve and this is at the heart of all we do, especially in our social innovation teaching and research" (Glasgow Caledonian University, 2015) - fitted well with our revised teaching, learning and assessment strategy.

As the Glasgow Science Centre was able to take only a limited number of groups, we approached other third-sector organisations. In the first year, we invited the University's People Services Health and Wellbeing department and Reaching Older Adults Renfrewshire (ROAR), as we were aware that each had a remit for health promotion for its respective employees and service users. In the second year, to accommodate growing student numbers, we identified, through our social networks, Waverley Care (HIV and Hepatitis C Charity), Turning Point Scotland (service provider for people from the criminal justice sector and addictions) and the Wing Hong Chinese Community Centre (Support centre for elderly Chinese in the south west of Scotland). In addition, the Department was approached by the Royal Scottish National Orchestra (RSNO) for opportunities to collaborate on research and teaching and learning. In discussion with the orchestra's manager, we identified that 


\section{Case Studies}

musicians were at risk of musculoskeletal injuries, owing to prolonged, and usually asymmetric, sitting postures. In partnership with the musicians, the students developed a seated exercise programme to be carried out during rehearsals, at home and in the concert hall, to prevent potential injuries from occurring. In addition, they advised musicians on 'micro-breaks' and posture management. Our final addition this year was the Glasgow Mosque, whose representatives approached us, specifically to work with us on the Health Promotion module with two groups of elderly residents who attended the mosque to participate in a social group.

Initially, we agreed to three visits to the community partners' sites; these were to take place during the trimester and involved students, lecturers and community partners. The first visit was to discuss with the partners the scope of the project, including the needs, resources and requirements of the partners and their service users/employees; the second visit was for the students to discuss their ideas, plans and risk assessments, in relation to the interactive health promotion activity; the third was to carry out the activity with service users/employees.

Furthermore, the module team decided to change the summative assessment from a health promotion programme to an interactive health promotion activity, to be carried out with the service users/employees of the organisation at the end of the module. In the previous year, we had also replaced the design of a patient information leaflet with a health promotion website, using free online web design software such as Wix, Weebly or Wordpress. The website's focus was not on a specific illness or disease, as the leaflet had been, but on the health topic of the health promotion activity - and it was designed with service users/employees of the community partnerships in mind.

We met with the new partners to share our module documentation and agree on timelines for student contact, so as to achieve - in view of expected increase in partner workload - a realistic amount of collaborative contact. We also decided to collaborate in the grading of the assessment. This meant that the community partners would award $50 \%$ of the students' grade and the module team the remaining $50 \%$. The overall mark was to be moderated by peer marking of the students, so that all parties were involved in generating the final mark. The partners received summative marking training prior to the module, which included discussion of the assessment criteria for the project and the criteria for MSc level study. As the partners had not marked summatively before, guidance would continue to be available during the marking process. Following the meeting, and before students came on the programme, the module team worked collaboratively with the partners to identify a relevant and suitable topic for the students and to help the partners to prepare for student visits.

(Originally, owing to partners' lack of experience, the module team had designed the summative assessment. In subsequent years, the team, the partners and the students collaborated to amend the assessment forms. For example, the section in the assessment form on 'professionalism' during visits to sites covered such aspects as appearance, responsiveness and timeliness, but the partners felt that 'team cohesion' should be added, since they wished to comment on this in their feedback.)

We therefore like to view the process of this module as a true partnership, a shared journey of learning for all involved. It marries educational philosophy with an approach that partners students, communities and the module team in health promotion; it acknowledges that there is learning in this for all of us. We all bring something to the table and take something away 


\section{Case Studies}

in our shared pursuit of opportunities to enhance the wellbeing of service users and employees. Our collaborative efforts support all of us and develop our knowledge and understanding of the health topic: students and the module team learn from service users/employees and their day-to-day lives; the community partners learn about the University and the processes involved in teaching, learning and assessment; service users/employees learn from students as they find out about what is involved in studying; students and the module team learn about the various resources that are available in the community and discover where health promotion opportunities can be created outside the $\mathrm{NHS}$; community partners receive potential resources for future use.

\section{How effective has our approach been?}

We set out with these module changes to enhance student engagement and develop students' capabilities as health promotion agents. We started with an attempt to share the learning journey between the module team and students and extended this to a three-way partnership with community partners.

In partnership, students produced a wide variety of health promotion activities and websites. For example, one group visited a ROAR community centre: the students joined elderly service users for their weekly lunch at the centre, before introducing their planned activity about 'smoothies'. It consisted of a tasting of various smoothies, a quiz to identify the vegetables and fruits included in them, a demonstration of how smoothies are made and a smoothie recipe hand-out (also made available through the website). The community partner had also obtained some funding to buy 'smoothie makers' for the service users; these were handed out to anyone willing to try the recipes at home, following the session. A second example was an activity about energy drinks for the public at the Glasgow Science Centre, on the floor of the BodyWorks exhibition. Children and families were invited to identify and define different types of drinks from a range of drinks cans and bottles, including flavoured waters, juices, sports drinks and energy drinks. The students then asked people to rank these drinks in order of sugar or caffeine.

We no longer experience incongruent student engagement. In contrast, we now receive very positive feedback from students, demonstrating what they value in working with community partners and the module team: "Gaining an insight into working with community groups and partnerships." Most students stated that they could see the role of physiotherapists as health promotion agents in the community. One of them said: "I understand that Health Promotion is a very important part of being a physiotherapist - I did not necessarily realise this in depth before I started the course, so in that regard I have found the course useful and insightful."

Concern is still raised about how this fits with their clinical practice, for their practice education is largely undertaken in NHS settings. Embedding of government strategies and guidance can take a long time and there is current tension between health promotion strategies and actual practice. This challenge is not unique to healthcare, nor to health promotion, but it raises the 'chicken-and-egg' scenario for higher education institutions. Do we merely prepare students for practice as it is currently delivered and wait for practice to change, or do we prepare students to help change these practices once they start working? We have opted for the latter, but this can be challenging when students are simultaneously getting to grips with current practice and grappling with concepts of 'future practice'. The module team addresses this by holding class-based discussions about this very challenge. 


\section{Case Studies}

Furthermore, the programme team is addressing the changing nature of healthcare provision by extending placements to, for example, the private and third sectors.

The student marks increased from an average mark in 2015 of $71 \%$ (range $62 \%-84 \%$ ) to an average mark of $75 \%$ (range $62 \%-85 \%$ ) in 2017 . Students were initially concerned about the influence of external, inexperienced markers on their grades. However, once they started receiving feedback and marks from the module team and the community partners, they were positive about partner input. We also, throughout the module, discussed the quality procedures we had in place to prepare the partners for the marking process.

Following completion of the module, community partners are invited to a meeting at the University, where, together, we look back at the module in terms of content, delivery and assessment, or, indeed, of any issue that may be raised. In addition, this meeting provides an opportunity for the third-sector organisations to network and develop relations with the other parties present.

The networking opportunities for the community partners have been fruitful: firstly, in terms of exchanges in ways of working; secondly, in terms of visits of service users to other partners. For example, ROAR, one of the third-sector organisations, runs services to encourage older people to remain active; it regularly runs a men's group which goes on field trips. The wellbeing coordinator at the University's People Services managed to arrange for this men's group to get a guided tour of the building works which were taking place on campus.

The feedback we received from one of our community partners confirmed that she appreciated the way we valued and respected the organisation's and service users' knowledge and practices throughout the collaboration. This included collaboration in choosing the topics for students' projects, provision of feedback and project guidance for students. The partner's appreciation of our collaboration was based on her previous negative experiences of working with other public-sector organisations. Another partner commented favourably on the way the module team collaborated with students.

So, what has been the benefit for our programmes? Whilst service users and third-sector organisations had been included in academic modules on our programmes previously, for example by inviting patients and carers to speak to students, this was the first module to put collaboration between students, community partners and the module team at the centre of the module. Community partners not only delivered some of the teaching, they also guided students by giving them formative feedback and provided half of the summative marks for students. As a result of relationships with the community partners, service users have become part of our quality procedures and now sit on the Programme Boards for all our programmes. Service users and the community partners were part of the development of a new programme and were interviewed as part of the accreditation process. Furthermore, as a result of working with community partners in settings where there currently is no provision of physiotherapy, we have included a 'role emerging' placement in our newly-accredited Doctorate in Physiotherapy pre-registration programme. The 'role emerging' placement offers students a valuable opportunity to continue working in partnership and to be creative and innovative in moving the profession forward - and thus to attain 'doctorateness'. 


\section{Case Studies}

\section{Conclusion}

In conclusion, the partnership between students, community partners and module team has been largely effective in achieving our original aim of enhancing students' engagement. However, its impact has been far greater than we could have anticipated.

It is vital that the module team can 'walk the walk' in any collaborative relationship with students and community partners. Successful partnership depends upon being authentic and honest, showing mutual respect and communicating well. The combination of a social constructivist and assets-based approach was in this instance fundamental to establishing a positive and shared learning journey for all involved.

\section{Reference list}

Allied Health Professions Federation (2015) A strategy to develop the capacity, impact and profile of allied health professionals in public health 2015-2018. Strategy from the Allied Health Professionals Federation supported by Public Health England. Available at: http://www.ahpf.org.uk/files/AHP\%20Public\%20Health\%20Strategy.pdf (Accessed: 29 November 2017).

Butin, D. (2010) Service-learning in theory and practice: The future of community engagement in higher education. New York: Palgrave MacMillan.

Christensen, J.H., Bønnelycke, J., Mygind, L. and Bentsen, P. (2016) 'Museums and science centres for health: from scientific literacy to health promotion.' Museum Management and Curatorship, 31(1),17-47. Available at:

https://www.tandfonline.com/doi/abs/10.1080/09647775.2015.1110710 (Accessed: 23 March 2018).

Council of Deans of Health (2017) Guidance: Public Health Content within the PreRegistration Curricula for Allied Health Professions. London: Council of Deans.

Felten, P. and Clayton, P. (2011) 'Service-Learning.' In: Felten, P., Clayton, P., Buskist, W. and Groccia, J.E. New Directions for Teaching and Learning, 2011(128), 75-84. Available at: https://onlinelibrary.wiley.com/doi/abs/10.1002/tl.470 (Accessed: 23 March 2018).

Glasgow Caledonian University (2015) University for the Common Good. Strategy 2020. Available at: https://www2.gcu.ac.uk/strategy2020/media/2020-Strategy-Brochure-OP.pdf (Accessed: 6 March 2018).

Higher Education Academy (2014) Framework for partnership in learning and teaching in higher education. Available at: https://www.heacademy.ac.uk/students-partners-frameworkaction\#sthash.3qm22uNX.dpuf (Accessed: 30 November 2017).

Naidoo, J. and Wills, J. (2016) Foundations for health promotion, 4th edition. London: Elsevier.

NHS Health Scotland (2011) Asset-based approaches to health improvement. Available at: http://www.healthscotland.com/documents/5535.aspx (Accessed: 6 March 2018).

Needle, J.J., Petchey, R.P., Benson, J., Scriven, A., Lawrenson, J. and Hilari, K. (2011) The allied health professions and health promotion: a systematic literature review and narrative synthesis. Final report. Southampton: NIHR Service Delivery and Organisation programme, $1-6$. 


\section{Case Studies}

Papworth, R. (2016) 'A multi-disciplinary, social constructivist approach to promoting student engagement, retention and achievement in higher education.' Dialogue, 3,.53-68.Available at: https://www.ceeol.com/search/article-detail?id=468909 (Accessed: 23 March 2018).

Radu, L. (2011) John Dewey and progressivism in American education. Bulletin. Brașov, Romania: Transilvania University of Brașov. Series VII, Vol. 4. 53(2), pp.85-90. Available at: http://webbut.unitbv.ro/BU2011/Series\%20VII/BULETIN\%20VII/03 4\%20Radu.pdf (Accessed: 23 March 2018).

Sawers, K.M., Wicks, D., Mvududu, N., Seeley, L. and Copeland, R. (2016) 'What Drives Student Engagement: Is it Learning Space, Instructor Behavior or Teaching Philosophy?' Journal of Learning Spaces, 5(2). Available at: http://libjournal.uncg.edu/jls/article/view/1247 (Accessed: 23 March 2018)

Trowler, V. (2015a) Critical engagement or selective affinity? Neoliberalism, tyrannical participation and the meanings of student engagement. CRLL conference 2015. Glasgow: Glasgow Caledonian University.

Trowler, P. (2015b) Ideological Reservoirs and Student Engagement. Available at: http://tinyurl.com/pmyg7gg (Accessed: 30 November 2017).

World Health Organisation (2017) Health Topics: Health Promotion. Available at: http://www.who.int/topics/health promotion/en/ (Accessed: 30 November 2017).

World Health Organisation (2016) Shanghai Declaration on promoting health in the 2030 Agenda for Sustainable Development. Available at:

http://www.who.int/healthpromotion/conferences/9gchp/shanghai-declaration.pdf?ua=1

(Accessed: 6 March 2018). 